\title{
Demand for inputs in silkworm production: the case of Turkey
}

\author{
Osman Orkan Özer ${ }^{*}$, Berrin Taşkaya Top²
}

\author{
${ }^{1}$ University of Adnan Menderes, Department of Agricultural Economics, Aydin, Turkey. \\ ${ }^{2}$ Republic of Turkey Ministry of Food Agriculture and Livestock, Agricultural Economic and Policy Development Institute, Ankara, Turkey.
}

\begin{abstract}
The objective of this study was to calculate the price, cross, and Morishima Technical Substitution elasticities for the costs of manpower, supply of mulberry leaves, transportation, heating, and material, all of which play pivotal roles for producers in sericulture. A survey was conducted by face-to-face interviews with 207 farmers within the scope of the study. At the analysis phase of the study, the share equity translog cost model was used. The response of the producers to the production input prices were calculated as inelastic. The strictest demand for an input belongs to mulberry leaves $(-0.051)$ and the highest elasticity for transportation costs $(-0.314)$. Sericulture dependents on workforce and mulberry leaves and this activity in Turkey is a labor-dense type of production.
\end{abstract}

Key Words: elasticity, sericulture, silkworm subsidies, translogcost model

\section{Introduction}

Sericulture in Turkey is an important agricultural activity in terms of ensuring rural development, considering its contribution to income and employment, and in terms of preserving the cultural heritage as well as the gene resources. Sericulture in Turkey is generally undertaken as a small scale complementary agricultural activity rather in mountainous areas, where the fields are not favorable for other agricultural activities. In the areas where this activity is undertaken, the sources of income of the producers are fairly limited. The production of the cocoon is usually made by the elders and women. In the production phase, the labor of all family members is involved in the process. In Turkey, sericulture, which does not require a lot of investment, contributed greatly to the utilization of the total family manpower in a total of 1760 farmers (1709 hybrids, 51 breeding silkworm producers) as of 2014, in addition to contributing to the employment in rural areas. Throughout the process, from the production of raw silk to its marketing, employment opportunities are presented to 500.000 people and an added value of 14 times is obtained

Received: April 5, 2017

Accepted: August 4, 2017

*Corresponding author: osman.ozer@adu.edu.tr

http://dx.doi.org/10.1590/S1806-92902017001200007

How to cite: Özer, O. O. and Top, B. T. 2017. Demand for inputs in silkworm production: the case of Turkey. Revista Brasileira de Zootecnia 46(12):917-923.

Copyright (C) 2017 Sociedade Brasileira de Zootecnia. This is an Open Access article distributed under the terms of the Creative Commons Attribution License (http://creativecommons.org/licenses/by/4.0/), which permits unrestricted use, distribution, and reproduction in any medium, provided the original work is properly cited. as the result of the cocoon, transformed into silk carpets (Kozabirlik, 2015).

Sericulture can be practiced in Turkey twice a year, in Spring and Fall. Turkey has a convenient geographical location for the cultivation of berry leaves and sericulture. However, sericulture and cultivation are practiced only in Spring because it is more economic during that season. In addition, the production phase is completed within a relatively short period of 35-40 days.

As of 2014, the cocoon production was undertaken in 37 provinces out of 81 in Turkey. In that year, $80 \%$ of the hybrid cocoon production was assumed by Antalya, Diyarbakır, Bilecik, Ankara, İzmir, and Sakarya provinces as the cocoon breeder production was done in Bursa and Bolu Provinces (Figure 1).

The only active producers' association in sericulture in Turkey as well as in the marketing channel of the product is the Cocoon Agricultural Sales Cooperatives Union Kozabirlik. Kozabirlik is a producer cooperative and its market share in domestic purchases reached $100 \%$ after the private sector left the market after 1995. All 125-130 tons of fresh cocoon and 2-3 t of breeder cocoon that are produced in Turkey annually are purchased by Kozabirlik.

The dry cocoon in Turkey is mainly used by Kozabirlik. An annual average of $50 \mathrm{t}$ of dry cocoon is processed and subsequently turned into raw silk by Kozabirlik.

The wet ball in Turkey is not a subject of import or export and the dry cocoon, raw silk, and silk yarn are traded in foreign trade markets. Sericulture-related products (seed, dry cocoon, raw silk) are not subjected to customs duties regarding their import. However, no subsidies are provided for the export of such products (MCT, 2013). 
A significant part of the imported raw silk and the silk yarn is used for the carpet manufacturing. An annual average of nearly $100 \mathrm{t}$ of the imported silk yarn is used by the carpet manufacturing businesses.

The amount of the imported raw silk and silk yarn varies depending on the domestic market and on the carpet exports. In Turkey, the majority of the raw silk is imported from Uzbekistan (47.8\%), China (30.4\%), and Turkmenistan (11.2\%), as $94 \%$ of the silk yarn imports are done from China (TurkStat, 2015).

Because there is no modern floater machine available in Turkey and the capacity of the cocoon that can be processed with shuttle system is limited, most of the cocoon produced in Turkey is exported. Therefore, Turkey is a net cocoon exporter and $80 \%$ of the exports are done to Iran and China (MCT, 2013).

As of 2002, sericulture activities in Turkey were supported by the state to keep the producers at their current locations, incite the production, protect and back sericulture, and contribute to rural development. Especially in terms of ensuring rural development, supporting the producers with low-level income bears vital importance. Within this context, it is imperative to keep the supports for the continuity of the production.

How the subsidies, offered for sericulture, influence the production depends on the extent to which production inputs are used. When implementing the support purchase policies, knowing the probable changes that the farmers may make in production inputs or knowing what other inputs would substitute that particular input and to what extent in prior are a necessity for the success of the support instrument.

In this study, the objective was to calculate the price, cross, and Morishima Technical Substitution elasticities

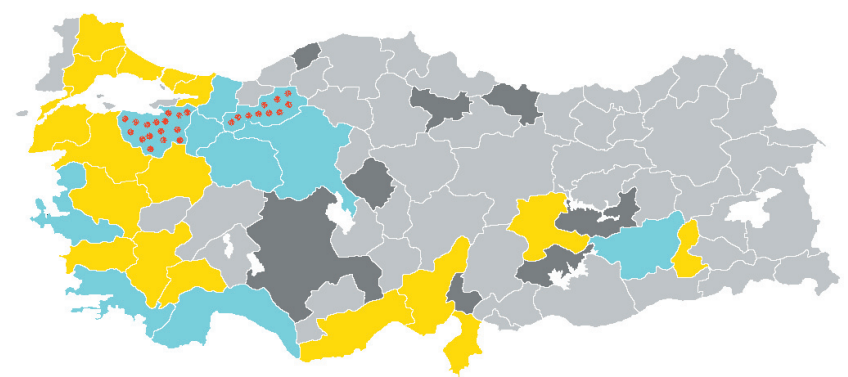

Blue: cocoon production of 97\%; yellow: 3\%; Grey: yield represents not received provinces.

The red dotted areas are provinces that constitute $100 \%$ of the breeding production.

Figure 1 - Sericulture-producing provinces of Turkey (2014). for the costs of manpower, supply of mulberry leaves, transportation, heating, and material, all of which play pivotal roles for producers in sericulture. The results exhibited the production function related to silkworm in Turkey.

\section{Material and Methods}

This study was performed with the participation of farmers that deal with hybrid and breeder sericulture. According to the records of Kozabirlik of 2013, amongst 2573 silkworm breeders, 170 farmers, who were selected from Diyarbakır, Antalya, and Bilecik provinces (making up $66 \%$ of the hybrid fresh cocoon production) by sampling method, represent the hybrid sericulturers. The breeders, on the other hand, are represented by 37 farmers, who could be reached on the field, out of 40 farmers from Bursa, who are active in the field of breeder sericulture as of the study year, and were evaluated by absolute counting method. Within this context, a survey was conducted by face-to-face interviews with 207 farmers in total within the scope of the study. Average annual values were calculated by dividing the total interviews.

When determining the number of hybrid farmers that take part in the study, the population of the study was formed by taking the fresh cocoon production in the provinces into account. From this population, the farmers were identified by random sampling method, which is used when the number and population of the main populace are known (Yamane, 1967).

The following formula was used for the determination of the sample volume:

$$
n=\frac{N t^{2} \sigma^{2}}{d^{2}(N-1)+t^{2} \sigma^{2}}
$$

in which $\mathrm{n}=$ volume of the sample and $\mathrm{N}=$ number of farmers within the population. The variance of the population is represented by $D^{2}=(d / t)^{2}$ and $d$ is accounted for the deviation within a specific rate, while $t$ corresponds to the $t$ table value (1.96) that corresponds to the reliability value that was predicted in the study (95\%).

In recent years, instead of using the Cobb-Douglas production functions, the use of flexible cost and profit functions, which are close to second degree Taylor Series, have become widespread in such studies (Binswanger, 1974; Tanrivermis, 2000; Miran et al., 2002; Dong and Mitchell, 2015; Kitenge, 2015). At the analysis phase of the study, the share equity translog cost model was used. For the analysis of the models, the Seemingly Unrelated Regression (SUR) model was utilized (Chiang, 1974). The 
translog cost function that was applied to the study was expressed by the following equation:

$$
\begin{aligned}
\ln (C)=\alpha_{0}+ & \sum_{i} \alpha_{i} \ln \left(w_{i}\right)+\frac{1}{2} \sum_{i} \sum_{j} \gamma_{i j} \ln \left(w_{i}\right) \ln \left(w_{j}\right)+\beta_{0} \ln (Q)+1 / 2 \beta_{0} \ln (Q)^{2} \\
& +\sum_{i} \beta_{i} \ln \left(w_{i}\right) \ln (Q)+\sum_{i} \delta \ln \left(w_{i}\right) \ln (L)+\sum_{i} \theta \ln \left(w_{i}\right) \ln (M) \\
& +\sum_{i} \pi \ln \left(w_{i}\right) \ln (E)+\sum_{i} \tau \ln \left(w_{i}\right) \ln (T)+\lambda_{1} \ln (\mathrm{L})+\lambda_{2} \ln (\mathrm{M}) \\
& +\lambda_{3} \ln (\mathrm{E})+\lambda_{4} \ln (\mathrm{T})+\varphi_{1} \ln (\mathrm{L}) \ln (\mathrm{M})+\varphi_{2} \ln (\mathrm{L}) \ln (\mathrm{E}) \\
& +\varphi_{3} \ln (\mathrm{M}) \ln (\mathrm{E})+\varphi_{4} \ln (\mathrm{L}) \ln (\mathrm{T}) \varphi_{5}+\ln (\mathrm{M}) \ln (\mathrm{T})+\varphi_{6} \ln (\mathrm{E}) \ln (\mathrm{T}) \\
& +\rho \mathrm{D}+\sum_{i} \omega \ln \left(w_{i}\right) \mathrm{D}
\end{aligned}
$$

In the equation, c represents the production cost per unit (the cost of production made per boxes), W represents the input price vector, $Q$ represents output amount, $M$ is used for the mulberry leaves (used for the production), $\mathrm{E}$ represents the heating expenses, and $\mathrm{T}$ represents the transportation expenses; D, on the other hand, is a dummy variable that represents the hybrid (1) or breeder $(0)$ sericulture of the producers; $\alpha, \beta, \gamma, \delta, \theta, \pi, \omega, \rho$, and $\lambda$ represent the parameters.

In the models, the costs, and revenue per box (10 $\mathrm{g}$ or about 20,000 pieces of silkworm larvae designated) were used as the data. In this way, they were intended to overcome the multi collinearity problem that may be resulted due to labor and other production input that are proportional to per box.

When the derivative of the translog variable cost function is calculated based on the logarithms of the changing factor prices, the cost share equations $\left(\mathrm{S}_{\mathrm{i}}\right)$ that provides the minimum input demand are obtained. This is called ( $\partial C / \partial P$ ) Sheppard's lemma (Shephard, 1970).

$$
S_{i}=\alpha_{i}+\sum_{j} \delta_{i j} \ln \left(w_{i}\right)+\beta_{i} \ln (Q)+\rho_{i} D
$$

This equation can be econometrically predictable with ease. At the same time, it is consistent with the limitations of the micro economic theory; thus, it is homogenous in degree zero based on the input prices. In short, when the input prices rise at the same rate, the cost sharing would not change (Miran et al. 2002).

The share equities should also be symmetrical to the cross-price elasticity. In addition, they should fulfill the condition that the sum of the shares equals to 1 (adding up). Therefore, the following limitations should be included in the model in forecasting the cost function (Fuller et al., 1999):

$$
\sum_{i} \alpha_{i}=1 ; \delta_{i j}=\delta_{j i} \text { and } \sum_{i} \gamma_{i j}=\sum_{i} \beta_{i}=\sum_{i} \rho_{i k}=0
$$

After the employability of the share equity model was tested, the Allen partial elasticity $(\theta)$ as well as the price and the cross elasticities $(\varepsilon)$ were calculated with the help of the parameters, obtained from the translog cost function via the below indicated formulas (Berndt and Wood, 1975; Greene, 2012):

$$
\begin{gathered}
\theta_{i j}=\frac{\delta_{i j}+S_{i} S_{j}}{S_{i} S_{j}}, \quad i \neq j \\
\theta_{i i}=\frac{\delta_{i i}+S_{i}\left(S_{i}-1\right)}{S_{i}^{2}} \\
\varepsilon_{i j}=\theta_{i j} * S_{j}
\end{gathered}
$$

With the help of the models, given based on the cost sharing equity, the input substitution elasticity between two inputs (labor - berry leaves) was calculated by the following formula, with the further assistance of the Morishima input substitution elasticity (Chiang, 1974):

$$
\sigma_{i j}^{M}=\varepsilon_{i j}-\varepsilon_{j j}
$$

Morishima input substitution elasticity measures the rational change in the utilization ratio of the factor pairs in tandem with the change in the price ratios of any given input pair (Chambers, 1988; Fuller et al., 1999). All of the SUR regression model computations were undertaken using the EViews 7.1 package.

\section{Results}

The survey revealed the socio-economic characteristics of silkworm producers. According to the result of the study, the young population within the mountain and forest villages drifts away from the agricultural production due to low income levels. The young manpower, living in villages, has been gradually decreasing as the result of the migrations from villages to urban areas due to the unemployment and to needs such as social security and education. This leads to the increase in the age of the producers. Among the sericulture farmers that were interviewed, $83.8 \%$ of the fresh cocoon producers were over 40 years old, while $20.3 \%$ were 65 and over. This situation demonstrates that the people in sericulture shall make up an even older population in the upcoming years. Therefore, it is predicted that the number of households engaged in sericulture shall drop significantly in the upcoming years.

For the producers, earning livelihood and pursuing the family business were the predominant purposes for engaging with sericulture. A total of $20.3 \%$ of the farmers do not perform any other agricultural activity, while $79.7 \%$ also engage in vegetable- or animal-based agricultural activities. Sericulture stands as an important source of income for low-income-level family farmers. As a matter of fact, $74.9 \%$ of the producers, who were interviewed within the scope of the study, indicated that sericulture constitutes a major agricultural source of income, while 
$17.4 \%$ also stated animal-based production and $6.8 \%$ stated crop production as a source of income.

The average annual income of the surveyed farmers was $€ 2,779.00$ (with the prices of 2014) and $32.53 \%$ of the total income is comprised of agricultural income (Table 1). The average annual income that the farmers generate from sericulture is $€ 494.00 /$ year and that counts for $54.7 \%$ of the total agricultural income, while the share of sericulture in the average annual income per farmer is $17.8 \%$. Sericulture is a very important source of income for the low-incomelevel family farmers. In fact, considering that the annual total income is quite low (€ 2,779.00) compared with the producers that involve into other agricultural activities, it is clear that the interviewed farmers absolutely need the income generated by sericulture.

The cocoon purchase prices in sericulture are announced by Kozabirlik. Kozabirlik purchases the breeder and hybrid cocoons of different prices. Since the cocoon yield in breeder producers is low, Kozabirlik sets the breeder cocoon prices over the poly-hybrid cocoon price. In addition, the defected cocoons that are not used for the yarn or breeder are also purchased by Kozabirlik with a different price, announced by Kozabirlik. As of 2013, the year in which the study was conducted, the purchase price for hybrid cocoon was $€ 1.61 / \mathrm{kg}$ as the purchase price for breeder cocoon was $€ 7.90 / \mathrm{kg}$ and the defected cocoon price was $€ 0.01 / \mathrm{kg}$ (Table 2 ).
The continuation of the subsidies is vital for the consistency of the production for preserving the historic and cultural values and saving sericulture from extinction. Seventy-two percent of fresh cocoon producers interviewed within the scope of this study indicated that the support is insufficient. Eighty-five point five percent stated that they would not continue the production unless the subsidies are in place. On the other hand, the producers also requested support for setting up breeding houses.

The interviewed producers pointed out the lowness of the fresh cocoon purchase prices and the lack of proper feeding places as the major factors that impact the production.

In this study, the translog cost function formed for sericulture was predicted for the factor prices (Table 3 ).

The independent variable material cost (MC), which is one of the cost sharing equations in the model, was excluded from the model. In this manner, it was possible to bring the sum of the estimated cost sharing to 1 . For the farmers in this study, the material costs include sack, waxed/craft paper, lime, net cleaning, and other materials. After all four cost shares were individually calculated, the material cost share was determined by the help of the limitations of the model $\left(\sum_{i} \alpha_{i}=1\right.$ and $\left.\sum_{i} \gamma_{i j}=\sum_{i} \beta_{i}=\sum_{i} \rho_{i k}=0\right)$. In this way, the cost model was rendered homogeneous and symmetrical.

In the analysis, the cross-price estimators were calculated symmetrically. The $\mathrm{R}^{2}$ values of the equations

Table 1 - Share of sericulture within the average total income of the interviewed farmers

\begin{tabular}{|c|c|c|c|c|c|}
\hline & $\begin{array}{l}\text { Hybrid income } \\
(€)\end{array}$ & $\begin{array}{l}\text { Breeding income } \\
(€)\end{array}$ & $\begin{array}{l}\text { Total income } \\
(€)\end{array}$ & $\begin{array}{c}\text { Share of agricultural } \\
\text { income }(\%)\end{array}$ & $\begin{array}{c}\text { Share in total income } \\
(\%)\end{array}$ \\
\hline 1 Sericulture & 464 & 615 & 494 & 54.65 & 17.78 \\
\hline 2 Animal production & 269 & 240 & 264 & 29.20 & 9.50 \\
\hline 3 Crops production & 136 & 35 & 117 & 12.94 & 4.21 \\
\hline 4 Agricultural income from outside own enterprises & 20 & 53 & 29 & 3.21 & 1.04 \\
\hline Total agricultural income & 889 & 943 & 904 & 100.00 & 32.53 \\
\hline Non-agricultural income & 1841 & 2030 & 1875 & - & 67.47 \\
\hline Total income & 2730 & 2973 & 2779 & - & 100 \\
\hline
\end{tabular}

Table 2 - Average production of the farmers

\begin{tabular}{|c|c|c|c|}
\hline & Hybrid & Breeder & General \\
\hline Average number of boxes & 2.11 & 2.4 & 2.17 \\
\hline Average fresh cocoon production $(\mathrm{kg})$ & 59.85 & 46.032 & 55.89 \\
\hline Average fresh cocoon production (kg/box) & 28.36 & 19.18 & 25.76 \\
\hline Average unused defective cocoons (kg) & 3.21 & 4.7 & 3.49 \\
\hline I- Fresh cocoon purchase price of Kozabirlik $(€ / \mathrm{kg})^{1}$ & 1.61 & 7.9 & - \\
\hline II- Defective cocoon purchase price of Kozabirlik $(€ / \mathrm{kg})$ & 0.01 & 0.01 & - \\
\hline III- Support payments $(€ / \mathrm{kg})$ & 7.14 & 7.14 & - \\
\hline Total cocoon purchase price $(€ / \mathrm{kg})(\mathrm{I}+\mathrm{III})$ & 8.75 & 15.04 & - \\
\hline Total defective cocoon purchase price $(€ / \mathrm{kg})(\mathrm{II}+\mathrm{III})$ & 7.15 & 7.15 & - \\
\hline
\end{tabular}

According to prices of 2013

${ }^{1}$ Class cocoon purchase price. 
regarding the estimated cost sharing varied between 94.102 and $32.006 \%$. Although the $\mathrm{R}^{2}$ value of the cost sharing, belonging to transportation costs, was low, the $\mathrm{R}^{2}$ value of the system was at $96 \%$.

The estimated elasticity for the farmers that produce fresh cocoon is an important source of data to reveal the production method and structure. By considering the signs of elasticity of cross price and substitution, we can identify them as substitution and complementary inputs. If the sign of the elasticity is positive and over zero, it means there is a possibility of substitution between the inputs. If the sign of the elasticity between the inputs is negative and below zero, that means those two inputs are complementary to each other (Chambers, 1988).

When the input demand elasticity that is estimated via the share equity model (Table 4 ) is analyzed, the strictest demand for an input belongs to mulberry leaves $(-0.051)$ The highest elasticity goes for transportation costs $(-0.314)$. Based on the analyzed elasticity values, it is safe to say that the response that the producers give to the changes of the inputs used for the production of silkworms is quite weak. In short, a price increase of $10 \%$ in mulberry leaves would only result in a demand decrease of $0.12 \%$. This shows that, in sericulture, the production of fresh cocoon is completely dependent on mulberry leaves. As a matter of fact, sericulture is exclusively undertaken in regions where fresh mulberry leaves can be adequately provided.

The response of the producers to the labor costs is also low and against a $10 \%$ rise in labor prices, it is revealed that the demand for labor drops only by $1.43 \%$ (Table 4 ). This situation demonstrates the dependence on the labor in sericulture. Utilization of dense handcraftsmanship in sericulture is the most important reason for weak responses to the prices. In addition, an increase of $10 \%$ in heating costs also meets with a weak response of $1.19 \%$.

When the cross-price elasticity is reviewed (Table 4), the mulberry leaves and the labor in labor share equity are complementary to each other. The other inputs are substitutions in nature. For the cost share equity for mulberry leaves, the labor and heating costs are complementary inputs with mulberry leaves. A $10 \%$ price increase in mulberry leaves results in a $5.91 \%$ increase in heating costs. The crosselasticity values are generally quite stringent and when the price of an input increases, such can only be substituted with another input at low levels. The highest substitution ratio was between the transportation and the material costs $(-0.586)$.

Table 3 - Parameters of the predicted cost sharing equities

\begin{tabular}{|c|c|c|c|c|c|}
\hline \multirow{3}{*}{ Independent variable } & \multicolumn{5}{|c|}{ Dependent variable } \\
\hline & \multicolumn{5}{|c|}{ Share of variable costs } \\
\hline & Labor cost & Mulberry cost & Heating cost & Transport cost & Material cost ${ }^{1}$ \\
\hline Labor price/material price & $0.19040(0.00281)^{*}$ & $-0.10829(0.00225)^{*}$ & $-0.00556(0.00304)^{*}$ & $-0.07641(0.00135)$ & 0.02239 \\
\hline Blade price/material price & $-0.11291(0.00426)^{*}$ & $0.15368(0.00341)^{*}$ & $0.00009(0.00462)^{*}$ & $-0.04058(0.00205)^{*}$ & -0.00418 \\
\hline Energy price/material price & $-0.06079(0.00333)^{*}$ & $-0.03040(0.00266)^{*}$ & $0.10673(0.00360)^{*}$ & $-0.01562(0.00160)^{*}$ & -0.00956 \\
\hline Silkworm yield & $0.06251(0.00649)^{*}$ & $0.03053(0.00519)^{*}$ & $-0.11234(0.00702)^{*}$ & $0.01916(0.00312)^{* *}$ & 1.03800 \\
\hline Dummy variable & $0.02697(0.00620)^{*}$ & $0.01880(0.00496)^{*}$ & $-0.04337(0.00671)^{*}$ & $-0.00281(0.00298)^{*}$ & 1.00363 \\
\hline $\mathrm{R}^{2}$ & 0.90940 & 0.94102 & 0.76991 & 0.32006 & \\
\hline Cost per share & 0.54031 & 0.23893 & 0.12203 & 0.09856 & 0.02743 \\
\hline
\end{tabular}

The standard errors are indicated within brackets.

${ }^{1}$ Calculated over total limitation.

$* \alpha=0.01$.

$* * \alpha=0.05$.

Table 4 - Price and substitution elasticity of the inputs used in silkworm production

\begin{tabular}{|c|c|c|c|c|c|c|c|c|c|c|}
\hline \multicolumn{6}{|c|}{ Price elasticity } & \multicolumn{5}{|c|}{ Morishima technical elasticity of substitution } \\
\hline & $\mathrm{L}$ & M & $\mathrm{E}$ & $\mathrm{T}$ & $\mathrm{MC}$ & $\mathrm{L}$ & M & $\mathrm{E}$ & $\mathrm{T}$ & $\mathrm{MC}$ \\
\hline $\bar{L}$ & -0.143 & & & & & & 0.131 & 0.348 & 0.693 & 0.716 \\
\hline M & -0.012 & -0.051 & & & & 0.039 & & -0.540 & 0.081 & 0.261 \\
\hline E & 0.205 & -0.591 & -0.191 & & & 0.396 & -0.400 & & 0.205 & -0.158 \\
\hline $\mathrm{T}$ & $(0.550)$ & 0.030 & 0.014 & -0.314 & & $(0.864)$ & 0.345 & 0.328 & & -0.271 \\
\hline $\mathrm{MC}$ & 0.573 & 0.210 & -0.349 & -0.586 & -0.280 & 0.853 & 0.490 & -0.068 & -0.305 & \\
\hline
\end{tabular}

$\mathrm{L}$ - labor price/material price; M - blade price/material price; $\mathrm{E}$ - energy price/material price; $\mathrm{T}$ - transport price/material price; $\mathrm{MC}$ - material cost. The elasticity values within the brackets are not statistically significant. 
If the Morishima technical substitution elasticity is higher than zero, then there is an imperfect substitution between those indicated inputs. According to this, when the substitution elasticity values are analyzed (Table 4), it is revealed that there is an imperfect substitution elasticity between labor and the other inputs. Based on this, the technical substitution elasticity between labor and the transportation cost was found as $0.693 \%$. This may be interpreted as when the transportation cost prices increase, the producer shall decrease its transportation costs and shall substitute it with more labor. In other words, instead of the transportation costs that the producers use for the transportation of mulberry leaves to be used in the production activities, the labor intensive transportation shall be used as a substitute. In short, the decrease in transportation costs shall be $0.693 \%$ of the labor:transportation ratio.

\section{Discussion}

The interviewed producers indicated that the low fresh cocoon purchase prices, the insufficient subsidies, and the lack of proper feeding areas are the most important factors that impact the production. However, there is no prior condition such as minimum production quantity to qualify the producers for the subsidies in Turkey. While the lack of such conditions ensures the sustainability of the production, it is not an incentive for increasing the efficiency. It is estimated that the number of producers in this field will decrease within the upcoming years.

Supporting the producers throughout the production phases and the consistence of the subsidy policies are vital. To increase their production, the supports and the purchase prices of Kozabirlik should be increased as well. In addition, providing supports towards forming breeding houses shall enable the producers to undertake the production under better conditions.

For fresh cocoon producers, the most effective factor is the price of cocoon. The lowness of cocoon prices causes producers to rip off their mulberry trees and to tend towards the more gainful agricultural activities (Başkaya, 2013). The other most important factor for giving up sericulture is the lack of workforce for especially breeding silkworm farmers. Although it creates income in a short period, the young population do not continue in sericulture and tend towards other professions because of its hard working conditions and intensive labor. The problems of obtaining mulberry leaves and the more profitability of other agricultural activities are the other reasons producers take into account for giving up sericulture (Top et al., 2015).

In case the obstacles that limit the production amount and the efficiency are removed, sericulture in Turkey has a potential to increase the income levels of the rural population and to contribute to the foreign currency reserves of Turkey through export activities.

\section{Conclusions}

The sericulture activities are carried out in areas without industrialization and the agrochemicals do not exist. Sericulture, which a labor-dense activity, does not require too much cost apart from the labor itself. Eighty-three point eight percent of the producers who carry out sericulture is over 40 years of age. The response of the producers to the production input prices are calculated as inelastic. Labor and mulberry leaf input elasticity values are calculated near to zero. This shows that sericulture is dependent on workforce and mulberry leaves. The mulberry trees used in nurture in Turkey are generally grown in mountainous villages, sides of roads, and areas free of agricultural chemicals. Therefore, sericulture is partly or wholly an organic agricultural activity.

\section{Acknowledgments}

This study has been derived from the study entitled "Determination of Socio-Economic Structure of Sericulture Farms in Turkey" conducted by the Ministry of Food, Agriculture and Livebreeder, the General Directorate of Agricultural Research and Policies.

\section{References}

Başkaya, Z. 2013. Development and distribution terms the place, distribution, problems and solutions of Bilecik District in Silkworm Breeding in Turkey. Eastern Geographical Review 18:257-286.

Berndt, E. R. and Wood, D. O. 1975. Technology, prices, and the derived demand for energy. The Review of Economics and Statistics 57:259-268. https://doi.org/10.2307/1923910.

Binswanger, H. P. 1974. A cost function approach to the measurement of elasticities of factor demand and elasticities of substitution. American Journal of Agricultural Economics 56:377-386.

Chambers, R. G. 1988. Applied production analysis: a dual approach. Cambridge University Press, Cambridge, England.

Chiang, A. C. 1974. Fundamental methods of mathematical economics. 2nd ed. McGraw-Hill, New York.

Dong, F. and Mitchell, P. 2015. Endogenizing sustainability in US corn production: A cost function analysis. Agricultural and Applied Economics Association \& Western Agricultural Economics Association, Milwaukee, USA. 
Fuller, F.; Koç, A.; Şengül, H. and Bayaner, A. 1999. Farm-level feed demand in Turkey. Center for Agricultural and Rural Development, Iowa State University, Iowa, USA.

Greene, W. H. 2012. Econometric analysis. New York University, Pearson, New York, USA.

Kitenge, E. 2015. Effects of food and agricultural imports on domestic factors in the U.S. agricultural sector: a translog cost function framework. Applied Economics Letters 23:132-137. https://doi. org/10.1080/13504851.2015.1058897.

Kozabirlik - Sericultural Cooperative Association of Turkey. 2015. Activities of Cooperative. Available at: $<$ http://www.kozabirlik.com.tr $>$. Accessed on: Nov 3, 2016.

MCT - Ministry of Customs and Trade - Turkey. 2013. "2013 Y1l1 İpekböceği Raporu". Available at: <http:// koop.gtb.gov.tr/data/5342b690487 c8ea5e4b4d9be/ 20\%C4\%B0pekb\%C3\%B6cek\%C3\%A7ili\%C4\%9Fi\%20Raporu.pdf $>$. Accessed on: Oct 12, 2015.
Miran, B.; Abay, C. and Günden, C. 2002. Pamukta girdi talebi: Menemen örneği. Ege Üniversitesi Ziraat Fakültesi Dergisi 39:88-95.

Shephard, R. 1970. Cost and production functions. Princeton University Press, Princeton.

Tanrıvermis, H. 2000. Orta Sakarya Havzası'nda domates üretiminde tarımsal ilaç kullanımının ekonomik analizi (Proje Raporu 2000-4).

Top, T. B.; Ucum, I.; Ozudogru, T.; Ozer, O. O.; Bars, T.; Polat, K. and Ataseven Yasan, Z. 2015. Sericulture in Turkey: Current situation, constraints and policies Conference: 7th Bacsa International Conference "Organic Sericulture - Now and the Future" "ORGASERI", Sinaia, Romania.

TurkStat - Turkish Statistical Institute. 2015. Foreign trade statistics. Available at: $<\mathrm{http}: / /$ www.turkstat.gov.tr/>. Accessed on: Oct. 12, 2015.

Yamane, T. 1967. Elementary sampling theory. Prentice Hall, Englewood Cliffs, N.J. 